\title{
The Effect of Current on Shear Strength and Nugget Size in Resistance Spot Welding of SCGA270D-45 sheet metal
}

\author{
Qamaruddin $^{1 *}$, R. Hengki Rahmanto ${ }^{2}$, Wahyu Setiadi ${ }^{2}$, Kiswiru Yudha Ningsih ${ }^{1}$ \\ \{*qamaruddin@stimar.ac.id\} \\ ${ }^{1}$ Sekolah Tinggi Ilmu Maritim (STIMar) “AMI” Jakarta \\ ${ }^{2}$ Universitas Islam "45" (UNISMA) Bekasi
}

\begin{abstract}
The objective of this paper is to present the effect of current on shear strength, nugget size and to determine the optimal current for spot welding SCGA270D-45 sheet metal of $0.8 \mathrm{~mm}$ thickness. The experimental steps conducted in the research were preparation of specimens, spot-welding process with variation of current $10.5 \mathrm{kA}, 11 \mathrm{kA}$, $11.5 \mathrm{kA}, 12 \mathrm{kA}$, and $12.5 \mathrm{kA}$; specimen testing; analysis and conclusion. Shear strength test was conducted by using tension machine and nugget size test by using Chisel test. Based on the research, it was found that the current variation has affected the shear strength and nugget size with highest current $12.5 \mathrm{kA}$ resulting shear strength $167.1 \mathrm{MPa}$ and nugget size $7.3 \mathrm{~mm}$; the lowest current of $10.5 \mathrm{kA}$ with $121.2 \mathrm{MPa}$ and $1.7 \mathrm{~mm}$ of shear strength and nugget size respectively. The optimal current for spot-welding SCGA270D-45 material with thickness $0.8 \mathrm{~mm}$ is $11 \mathrm{kA}$ for components belong to Acategory as per requirement of Toyota Engineering Standard TSH5600G.2012. Spot Welding.
\end{abstract}

Keywords: Resistance spot welding, shear strength, nugget size, Methodology SCGA270D-45 sheet metal

\section{Introduction}

Resistance spot welding is the common method widely used to join shet metals, particularly in automotive industry. Typically, there are about 2000-5000 spot weld in a modern vehicle [1]. There are three main parameters which control the quality of resistance spot welding namely: current, pressure and time [2]. In this paper, it will be presented the case of resistance spot welding which was found in automotive industry, that is the problem of joining the components of body and panel. The problem is regarding the quality of joining was not so good that the spot-welded components made of material sheet were broken. Therefore, improving the quality to meet standard as required by conducting experiment, is of great importance.

\section{Methodology}

The flow of research is roughly depicted as shown in Figure1. 


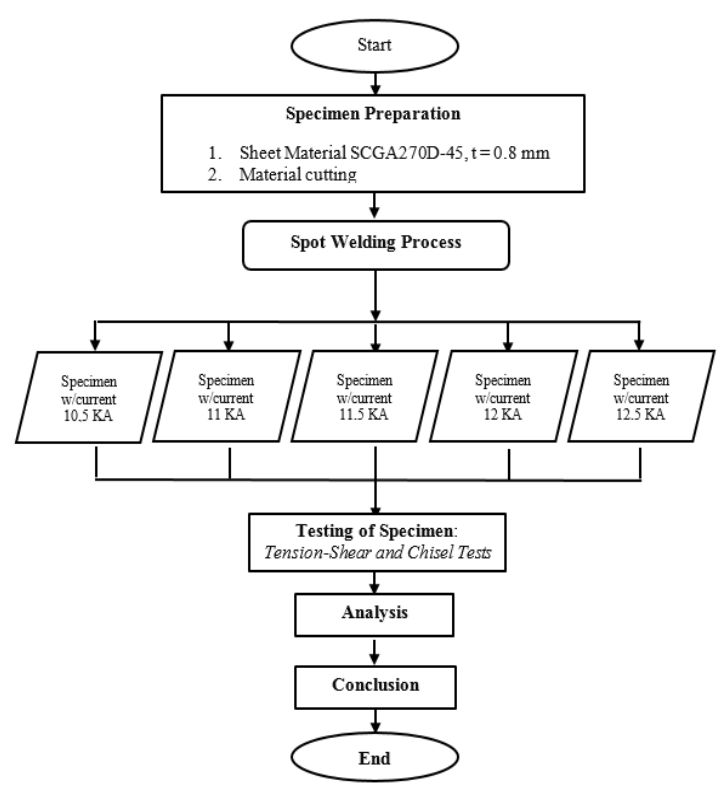

Fig. 1. The flow of research

The research was starting from specimen preparation, then conducting spot welding process by applying variation of current $10.5 \mathrm{kA}, 11 \mathrm{kA}, 11.5 \mathrm{kA}, 12 \mathrm{kA}$ and $12.5 \mathrm{kA}$. After the welding process, the specimens were then tested using tension-shear and Chisel tests. After the tests, conducting analysis and finally drawing conclusion.

\subsection{Material preparation}

Material used in this experiment, is SCGA270D-45 sheet, thickness $0.8 \mathrm{~mm}$ and dimension as standardized by Toyota Engineering Standard TSH5600G Spot Welding, is as shown in Figure 2.

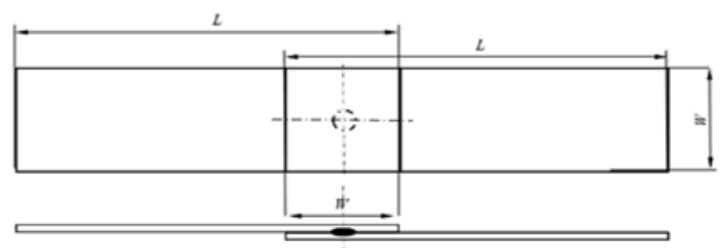

Fig. 2. Specimen dimension

Table 1: Specimen dimension as specified by standar

\begin{tabular}{|c|c|c|}
\hline $\begin{array}{c}\text { Sheet } \text { Thickness } \\
\mathrm{mm}\end{array}$ & $\begin{array}{c}\text { Width }(W) \\
\mathrm{mm}\end{array}$ & $\begin{array}{c}\text { Length }(\mathrm{L}) \\
\mathrm{mm}\end{array}$ \\
\hline up to 0.8 & 20 & 75 \\
\hline 0.8 to 1.3 & 30 & 100 \\
\hline 1.3 to 2.5 & 40 & 125 \\
\hline 2.5 to 3.2 & \multirow{2}{*}{50} & 150 \\
\hline 3.2 and other & & \\
\cline { 1 - 1 } & & \\
\hline
\end{tabular}




\subsection{Equipments}
a. Shearing machine
b. Welding machine
c. Tension test machine
d. Chisel test
e. Digital camera
f. Vernier caliper

\subsection{Experimental procedure}

The material sheet SCGA270D-45 with $0,8 \mathrm{~mm}$ thickness was cutted by using shearing machine in accordance with table 1, namely for thickness $0.8 \mathrm{~mm}$, width $30 \mathrm{~mm}$ and Length $100 \mathrm{~mm}$. The quantity of specimen used for each test was 3(three) pcs per each current variation. The result of the experiment was taken as average of the three specimens.

The respective sheet was then welded by spot-welding machine. The sheet condition was, before and after being welded, shown in Figure 2.

The result of spot welding process was then tested using Chisel-test, to determine the nugget size. The nugget dimension was subsequently measured and compared to standard of Toyota Engineering Standard TSH5600G Spot Welding with regard to quality as required by company. In addition to Chisel test, it was also conducted Tension-shear test to measure the strength of specimen as a result of spot welding.

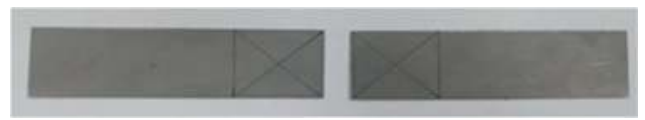

(a)

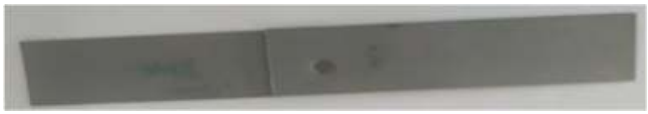

(b)

Fig. 3. Material sheet (a) before spot welding and (b) after spot welding

\section{Result and Discussion}

The chemical composition and mechanical properties of sheet is shown in Table 2.

Table 2. The chemical composition and mechanical properties SCGA270D-45

\begin{tabular}{|c|c|c|c|c|c|c|c|c|}
\hline \multicolumn{3}{|c|}{ Tensile Test } & \multicolumn{6}{|c|}{ Chemical Composition } \\
\hline $\begin{array}{c}\text { YS } \\
\left(\mathrm{Nmm}^{2}\right)\end{array}$ & $\begin{array}{c}\text { TS } \\
\left(\mathrm{Nmm}^{2}\right)\end{array}$ & $\begin{array}{c}\text { EL } \\
(\%)\end{array}$ & C & Si & Mn & P & S & Ti \\
\hline 167 & 325 & 44 & 0,001 & 0,01 & 0,13 & 0,001 & 0,0006 & 0,02 \\
\hline
\end{tabular}

The parameter used during spot welding process is shown in Table 3.

Table 3. The parameter in spot welding

\begin{tabular}{|c|c|c|c|}
\hline No & $\begin{array}{c}\text { Current } \\
(\mathrm{kA})\end{array}$ & $\begin{array}{c}\text { Resistance } \\
(\mathrm{Ohm})\end{array}$ & $\begin{array}{c}\text { Welding } \\
\text { time } \\
(\text { second })\end{array}$ \\
\hline 1 & 10.5 & 0.395 & 2.2 \\
\hline 2 & 11.0 & 0.395 & 2.2 \\
\hline 3 & 11.5 & 0.395 & 2.2 \\
\hline 4 & 12.0 & 0.395 & 2.2 \\
\hline 5 & 12.5 & 0.395 & 2.2 \\
\hline
\end{tabular}




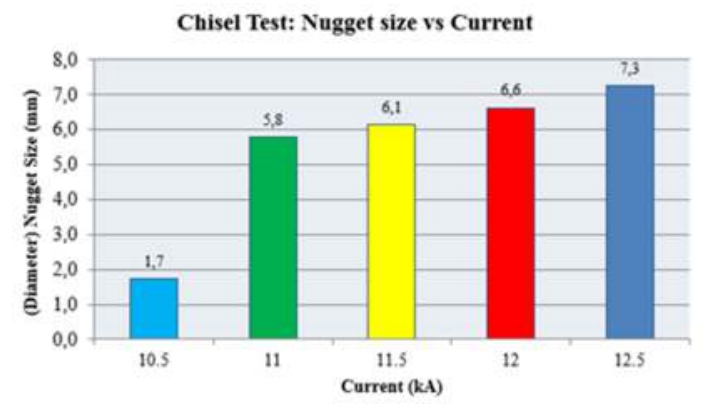

Fig. 1. Nugget size (average) vs Current.

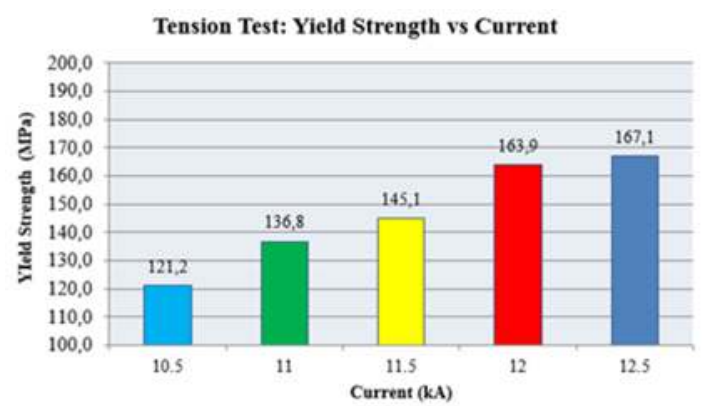

Fig. 2. Yield Strength (average) vs Current.

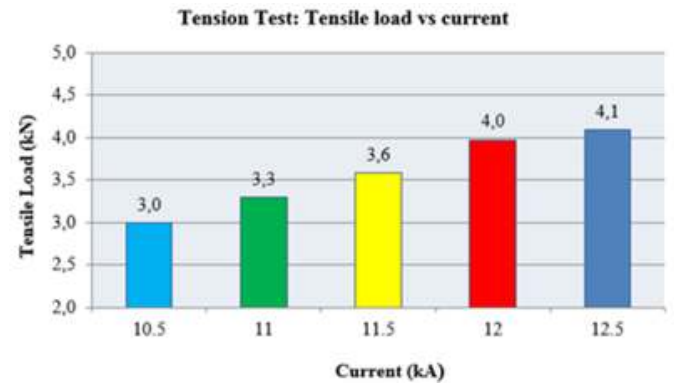

Fig. 3.Tensile Load (average) vs Current

Based on the graph 1, it can be seen that the increase of current resulted the increase of nugget size. Heat transfer is a function of time and the development of the nugget size requires a minimum length of time, regardless of amperage [2]. As the current control the heat generated according to the equation $\mathrm{Q}=\mathrm{I}^{2} \mathrm{Rt}$, the heat has influenced on the nugget diameter.

In graph 2, it is shown the correlation between yield strength and current, that the increase of current has increased the yield strength. The highest current $12.5 \mathrm{kA}$ has influenced on shear strength $167.1 \mathrm{MPa}$ and nugget size $7.3 \mathrm{~mm}$ and the lowest one $10.5 \mathrm{kA}$ has affected 121.2 $\mathrm{MPa}$ and $1.7 \mathrm{~mm}$ of shear strength and nugget size respectively. The result of this experiment is in line with previous one showing that increase of welding current magnitude has affected the increase of shear strength.

In graph 3 , the increase of current has caused the increase of tensile load, which is the highest load $4.1 \mathrm{kN}$ obtained as a result of $12.5 \mathrm{kA}$. 
As can be seen in table 4 , the minimum nugget size for sheet $0.8 \mathrm{~mm}$ is 4.5 for A-category and in Table 5, the minimum tensile load for the respective sheet is $3.23 \mathrm{kN}$.

Referring to required standard of company as mentioned in [3], shown in table $4 \& 5$ and referred to graph $1 \& 3$ as a result of the experiment, it can be seen that the optimum current for spot welding process for this material sheet $0.8 \mathrm{~mm}$, is $11 \mathrm{kA}$. The macro appearance of the specimens applied to $11 \mathrm{kA}$ is shown on Figure 3, which qualitatively remains acceptable under standard as required by company.

Table 4. Nugget Diameter (minimum).

\begin{tabular}{|c|c|c|c|}
\hline \multirow{2}{*}{$\begin{array}{c}\text { Sheet } \\
\text { thickness } \\
\text { (mm), T }\end{array}$} & \multicolumn{3}{|c|}{ Nugget diameter $(\mathbf{m m})$} \\
\cline { 2 - 4 } & $\begin{array}{c}\mathbf{A} \\
\text { category }\end{array}$ & $\begin{array}{c}\text { B } \\
\text { category }\end{array}$ & $\begin{array}{c}\text { C } \\
\text { category }\end{array}$ \\
\hline 0.5 & 3.5 & 2.8 & 2.1 \\
\hline 0.6 & 3.9 & 3.1 & 2.3 \\
\hline 0.7 & 4.2 & 3.3 & 2.5 \\
\hline 0.8 & 4.5 & 3.6 & 2.7 \\
\hline 0.9 & 4.7 & 3.8 & 2.8 \\
\hline 1.0 & 5.0 & 4.0 & 3.0 \\
\hline 1.2 & 5.5 & 4.4 & 3.3 \\
\hline Formulas & $5 \sqrt{T}$ & $4 \sqrt{T}$ & $3 \sqrt{T}$ \\
\hline
\end{tabular}

Table 5. Tensile Load (minimum).

\begin{tabular}{|c|c|c|c|}
\hline \multirow{2}{*}{$\begin{array}{c}\text { Sheet } \\
\text { thickness } \\
\text { (mm), T }\end{array}$} & \multicolumn{3}{|c|}{ Tensile Load (kN) } \\
\cline { 2 - 4 } category & $\begin{array}{c}\text { A } \\
\text { category }\end{array}$ & $\begin{array}{c}\text { C } \\
\text { category }\end{array}$ \\
\hline 0.5 & 1.61 & 1.32 & 0.98 \\
\hline 0.6 & 2.11 & 1.73 & 1.27 \\
\hline 0.7 & 2.65 & 2.16 & 1.62 \\
\hline 0.8 & 3.23 & 2.65 & 1.96 \\
\hline 0.9 & 3.82 & 3.14 & 2.35 \\
\hline 1.0 & 4.54 & 3.72 & 2.74 \\
\hline 1.2 & 5.88 & 4.90 & 3.83 \\
\hline
\end{tabular}

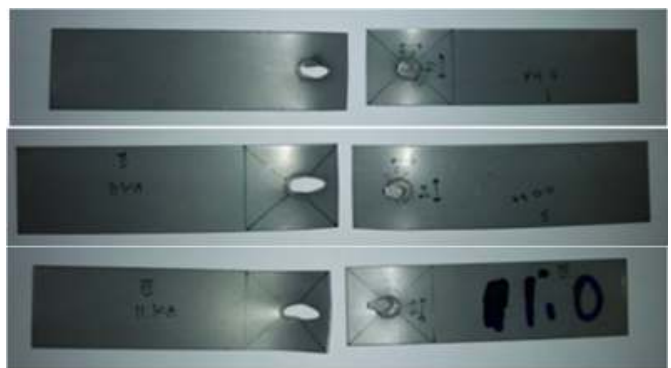

Fig. 4The macro appearance of three specimen after Spot Welding with $11 \mathrm{kA}$

\section{Conclusion}

Based on the result and discussion, the following conclusion can be drawn:

a. The variation of current has affected the shear strength and nugget size. The highest shear strength $167.1 \mathrm{MPa}$ and nugget size $7.3 \mathrm{~mm}$ was found as a result of current 
$12.5 \mathrm{kA}$; the lowest $121.2 \mathrm{MPa}$ and $1.7 \mathrm{~mm}$ of shear strength and nugget size respectively was obtained as a result of $10.5 \mathrm{kA}$.

b. The optimal current for spot-welding SCGA270D-45 material with thickness $0.8 \mathrm{~mm}$ is $11 \mathrm{kA}$ for components belong to A-category of [3].

\section{References}

[1] et al Akkas, N., "The Effect of Nugget Size on Mechanical Properties in Resistance Spot Welding of S235JR (Cu) Steel Sheets Used in Railways Vehicles," ACTA Phys. Pol. A, vol. 130, no. $1,2016$.

[2] K. M. Pandey, A. K., Khan, M. I., \& Moeed, "Investigation of the Effect of Current on Tensile Strength and Nuget Diameter of Spot Welds Made on AISI-1008 Steel sheet," Int. J. Tech. Res. Appl., vol. 1, no. 1, pp. 1-8, 2013.

[3] Toyota Engineering Standard, "TSH5600G," Spot Weld., 2012.

[5] H. . Mulyasa, Pengembangan dan Implementasi Kurikulum 2013. Bandung: Remaja Rosdakarya, 2013.

[6] R. Boyatzis, D. Goleman, and K. Rhee, "Clustering Competence in Emotional Intelligence: Insights from the Emotional Competence Inventory (ECI)," in Handbook of emotional intelligence, San Francisco: Jossey-Bass, 2000.

[7] W. R. Borg and M. D. Gall, Research Education: an Instruction. New York: Longman Tnc, 1983. 